\title{
Trap with a Green Fence (Treblinka, slovo jak z dětské říkanky)
}

\author{
Author: Richard Glazar
}

First Published: in German 1992, in Czech 1994.

Translations: German (Die Falle mit dem grünen Zaun, 1992); Czech original (Treblinka, slovo jak $z$ dětské ř́kanky, 1994); English (Trap with a Green Fence, 1995); Russian (Ad za zelenoj izgorodju, 2002); Polish (Stacja Treblinka, 2011); Dutch (Ontsnapt uit Treblinka, 2016).

About the Author: Richard Glazar (1920-1997), was born in Prague in a Czech Jewish family as Richard Goldschmid. He started studying economics until Czech universities were closed in November of 1939. Then he found a job in agriculture in the countryside. That did not save him from deportation to Theresienstadt first, and then to Treblinka, where he was assigned to work. He took part in the Treblinka Uprising and succeeded to escape together with Karel Unger. While walking across Poland they made up a story of a false identity in case they would be captured. Their story was believable enough to be sent as forced labourers to a steel industry in Mannheim, Germany. They remained there until the liberation. After the end of the war Glazar returned to Prague and reunited with his mother. All of his other relatives perished during the war. He went back to study economics and languages. He married and worked as a civil servant at a ministry. During Stalinist antisemitism (Slánský trial) 1951-1953, he quit his job and went to work in the steel industry again. In the 1960s he became a librarian in the Czechoslovak Academy of Sciences and published two books about urbanism. After the Prague Spring and during the Russian invasion in 1968 he fled to Switzerland and took a copy of the finished manuscript of his book Trap with a Green Fence with him. He became known through his appearance in the documentary Shoah by Claude Lanzmann. In 1963 and 1971 he testified against Nazi perpetrators in Treblinka trials in Düsseldorf. In the 1990s he often spoke in public about his experiences in the concentration camp Treblinka and at one such lecture he was asked to publish his book. In 1995 he returned to Prague. After the death of his wife he committed suicide due to his traumatic experiences from the war.

Further Important Publications: Veselý nebo Lustig (2003, Veselý or Lustig; memories and Jewish anecdotes).

\section{Content and Interpretation}

Richard Glazar writes from the perspective of his own autobiographical narrator. The story is divided into 34 chapters, starts with the school year of 1938, goes on to young adulthood, transport call to Theresienstadt, arrival and stay in the concentration camp Treblinka, planning the uprising, escape and survival till liberation in Germany as well as postwar years. 
The book opens with the chapter Fouling the Stars with the Dust of the Earth... a phrase from a poem in a fictionalised memoir The Grass Roof by Y. Kang (1937). Glazar finishes his secondary education and spends two months at University in Prague until it is closed by the Nazis. In the spring 1940, his parents send him to a more secure place to work in agriculture outside of Prague. He lives there for two years, taking care of cattle and reading at night. Younghill Kang's book The Grass Roof about the Japanese occupation of Korea represents his idea that history is somehow repeating itself. In September of 1942, Glazar is first deported to Theresienstadt for a month. The overpopulation and hunger there strikes him and he encounters some members of his family for the last time. Soon he receives the order to go on another transport to Treblinka. His first idea upon arrival is that it is an agricultural farm and they will need farmers like him. But in fact, Treblinka is a death camp.

Eli, Eli - They have thrown us into the fire and flames, the title of the seventh chapter is a song sung by a Polish opera singer, while bodies are being burned in Treblinka. Glazar assumes it is an ancient Jewish song describing the fate of Jews from hundreds of years of antisemitic history starting with the Spanish inquisition. This is one of the strongest moments of the book.

In the chapter The Uniformed Riders Glazar mentions the myths about what happens with the prisoners' wealth collected in Treblinka, and Glazar is assigned to sort the property. Ancient jewellery passing through generations lies there in bundles and creates a black market between the inmates and the guards. Glazar supposes many years after the war that treasures are still buried there (see $\rightarrow$ The Empty Field). This part of the book questions the assumption that the world has not known about the killing sites and leads to assumptions of the world about who has forgotten the Jews and to a sentiment to restore the importance of Jews for the world.

To regain a sense of humanity and life, inmates in the camp unite to revolt, destroy the killing site and show their worthiness to the world. Following chapters depict the revolt. Symbolically the headquarters of the uprising are based in the latrines. The revolt is portrayed as a plan with ups and downs and carried out by improvisations. Glazar has a sense for situational humour and shows sarcasm about the looks, clothes, and mischiefs of inmates. One example is when they obtain the key to the munitions depot and steal the explosives but forget the igniter.

Finding their way through Poland after the successful escape is a matter of going "to the left and sometimes to the right". Their journey continues in a humorous way and the refugees reach the Protectorate of Bohemia and Moravia. Nevertheless, in fear of being discovered, they decide to hide in Germany as Czechs, employed in the war industry. In Mannheim, after the bombing by the Americans has started, they cannot find any food but discover a lot of wine that has been left behind, so they drink the wine and stay drunk until the moment of their liberation.

In 1948 the new Communist government built a fence around Czechoslovakia. Soviet occupation in 1968 made him recall the Russian and Ukrainian guards in Treblinka. He decides to escape from Czechoslovakia. 
While German, English and other editions of the book have been published in abbreviated versions, the Czech edition presents the author's entire manuscript with the original title Treblinka, Like a Word from a Children's Rhyme. The third Czech edition from 2012 is accompanied by family pictures mostly from Glazar's book Veselý or Lustig.

\section{Main Topics and Problems}

There are only a few sources about Treblinka, this is why Glazar's book is considered both a literary work for its style and a historical source for its information.

In the chapter called The Name Treblinka he discusses where this name comes from. "Treblinka - to people outside, in life, it may sound like a friendly name." (Glazar, 1995, p. 19) Upon arrival with the transport, he sees a boy in a forest. The boy "grabbed his neck with both hands, aped strangulation, rolled his wide-open eyes, and stuck out his tongue" (Glazar, p. 8). On the other hand the German and English titles refer to the green fence hiding a trap. Later during his time in the concentration camp it was Glazar's task to camouflage the camp by keeping the fence hidden behind fresh green branches.

The author's survival strategy is to appear strong and human: as the main character Glazar seems to carefully analyse and observe the German guards say that it is important to stand up straight and look in a good shape, this increases his chances of staying alive and decreases the probability of being punished. Another survival strategy expressed in the story is situational humour and a lack of willingness to subordinate oneself that is reminiscent of the strategies in Jaroslav Hašek's Stories of the Good Soldier Švejk.

Glazar is also intrigued by the Polish Jewish spirituality. He and his friends have non-religious backgrounds and a different mentality. Glazar depicts the clash of moral values and comradeship as well as religious obedience between the Polish Jews from the East and the Czech Jews.

Arrivals of transports are perceived as a paradox while the inmates should be sad, they are aware that the new arrivals will save them from starvation. Descriptions of grotesque situations about how they try to get a hold of the food follow.

The mixture of Slavonic languages with orders in German is used as a lingua fran$c a$ to communicate with other inmates in the camp. The aspect of multilingualism is one of the reasons to believe the novel turns away from facticity to give way to literary style and humour. Glazar could not have remembered entire discussions in their proper dialect. On the other hand the recreation of the camp dialect gives an impression how people from different countries could communicate with each other.

Glazar has influenced authors like Jáchym Topol ( $\rightarrow$ The Devil's Workshop) for his usage of multilinguistic expressions in Czech and German.

\section{Cited Work}

Glazar, Richard (1995). Trap with a Green Fence, Survival in Treblinka. Evanston, Illinois: Northwestern University Press. 


\section{Further References}

Balík, Š. (2014). Ewangelia o Treblince według Glazara, Rajchmana, Wiernika, Willeberga. In: G. Gazda, M. Leyko, P. Rutkiewicz, eds., Reprezentacje Shoah w literaturze i filmie w Europie Środkowej: lata powojenne. Acta Universitatis Lodziensis, vol. 11. Łódż: Wydawnictwo Universytetu Łódzkiego, pp. 49-62. Available at: https://sites.ff.cuni.cz/ holokaust/wp-content/uploads/sites/122/2013/11/stepan-balik-ewangelia-o-treblince. pdf [Accessed: 10.2.2020]. Cieslar, J. (2002). Treblinka, slovo jak z dětské říkanky. In: J. Cieslar. Hlas deníku. Praha: Torst, pp. 249-253. Davies, P. (2018). Linguistic Diversity and Political Solidarity in Richard Glazar's Treblinka Memoir Die Falle mit dem grünen Zaun. The Modern Language Review, 113(4), pp. 794-810. Available at: https://www. jstor.org/stable/10.5699/modelangrevi.113.4.0794 [Accessed: 08.12.2019]. Jürgens, Z. (2010). Zeugen und Erben der Geschichte: Der Holocaust in der tschechischen Literatur (Richard Glazar und Jáchym Topol). In: M. Marszalek, A. Molisak, eds., Nach dem Vergessen. Rekurse auf den Holocaust in Ostmitteleuropa nach 1989. Berlin: Kulturverlag Kadmos, 2010, pp. 217-232.

HN 